\title{
PENGEMBANGAN MODUL KESETIMBANGAN KIMIA BERBASIS PENDEKATAN SAINTIFIK UNTUK KELAS XI SMA/MA
}

\author{
Yerimadesi, Bayharti, Fitri Handayani, Wiwit Fitrah Legi \\ Juirusan Kimia Jurusan Kimia FMIPA, Universitas Negeri Padang. \\ Jalan Prof. Dr. Hamka Air Tawar Barat Padang \\ Email: yerimadesi_74@yahoo.com
}

\begin{abstract}
This developmental research aimed to produce scientific approach-based module in chemistry equilibrium topic, determine its validity, practicality, and effectiveness on grade XI students' learning outcome. It was based on 4-D development model that included defining, designing, and developing stage. Module was validated by expert and tested to senior high school (SMA) students. Research instruments used were questionnaire in the form of validity and practicality sheets and learning outcome test. Validity sheets were completed by 5 chemistry lecturers and 3 chemistry teachers. Practicality sheets were completed by 4 chemistry teachers and 25 grade XI students in public SMA (SMAN) 2 Batusangkar. Data were analyzed with Kappa Moment. The mean score of Kappa Moment for validity was 0.84 indicating a high degree of validity. The mean score of Kappa Moment for practicality were 0.87 (for students) and 0.84 (for teachers) indicating a very high degree of practicality. Effectiveness of the module was obtained from cognitive test score of students in SMAN 4 Padang. Analysis showed that the test score of students taught with module was siginificantly higher than that of students who were not. It can be concluded that the module developed was valid, practical, and effective for senior high school instruction.
\end{abstract}

Key words: chemistry equilibrium, module, scientific approach.

\section{PENDAHULUAN}

Pendekatan saintifik (scientific approach) merupakan salah satu pendekatan pembelajaran yang berorientasi atau berpusat pada siswa. Pendekatan ilmiah sering juga disebut sebagai metode ilmiah. Metoda ilmiah pada dasarnya bukanlah kumpulan langkah-langkah ilmiah berurutan yang harus terjadi, walaupun kadangkadang disajikan seperti itu. Metoda ilmiah bukan hanya untuk pelajaran yang memerlukan kerja laboratorium, namun dapat diaplikasikan ke semua bidang ilmu pengetahuan untuk membantu pemahaman siswa tentang suatu ilmu pengetahuan (Lewis, Gary. TT). Hal ini sesuai dengan kurikulum 2013 yang menekankan pelaksanaan pendekatan saintifik pada semua jenjang pendidikan (Permendikbud Nomor 59 Tahun 2014). Pendekatan saintifik dalam pembelajaran akan lebih mudah dilaksanakan jika tersedia bahan ajar. Oleh karena itu pengintegrasian pendekatan saintifik ke dalam bahan ajar merupakan salah satu upaya yang dapat dilakukan guru untuk membantu penerapan pendekatan saintifik.

Salah satu bahan ajar yang dapat meningkatkan keaktifan dan pemahaman siswa terhadap materi pelajaran adalah modul. Modul merupakan seperangkat bahan ajar yang disajikan secara sistematis dan lengkap sehingga penggunanya dapat belajar dengan atau tanpa guru, dengan modul siswa dapat belajar secara individu di sekolah maupun di rumah sesuai kecepatan belajarnya masingmasing (Prastowo, Andi. 2011). Sawitri (2014) melaporkan bahwa modul berbasis pendekatan saintifik sangat layak digunakan dalam 
pembelajaran keanekaragaman hayati. Yerimadesi, dkk (2015) melaporkan bahwa bahan ajar larutan penyangga dalam bentuk modul berbasis discovery learning valid dan praktis digunakan untuk pembelajaran kimia SMA/MA, $81,63 \%$ siswa bisa menjawab pertanyaan-pertanyaan yang ada pada modul dengan benar, sehingga modul ini dapat direkomendasikan untuk digunakan dalam kegiatan pembelajaran kimia kelas XI di SMA/MA.

Kesetimbangan kimia merupakan salah satu materi pokok kimia SMA/MA yang dipelajari di SMA/MA kelas XI semester ganjil. Berdasarkan analisis terhadap kompetensi dasar (KD) dan pengembangan indikator, disimpulkan bahwa pada materi ini, siswa dituntut agar dapat memahami konsep-konsep secara teoritis dan melalui percobaan, sehingga siswa dapat menemukan fakta, konsep dan prinsip yang terdapat di alamnya. Materi ini juga membutuhkan latihan karena terdiri atas perhitungan-perhitungan. Oleh karena itu dapat disampaikan oleh guru dengan metoda, teknik, model dan pendekatan pembelajaran yang beragam serta media pembelajaran yang bervariasi.

Hasil penelitian menunjukkan bahwa penerapan pendekatan saintifik pada materi kesetimbangan kimia efektif dalam meningkatkan keterampilan elaborasi siswa. Rata-rata $n$-gain keterampilan elaborasi dengan pendekatan saintifik lebih tinggi dari pada ratarata n-gain keterampilan elaborasi dengan pembelajaran konvensional (Purwaningsih, dkk, 2014).

Berdasarkan latarbelakang di atas maka dilakukan penelitian yang bertujuan untuk menghasilkan modul kesetimbangan kimia berbasis pendekatan saintifik, menentukan tingkat validitas, praktikalitas dan efektifitasnya terhadap hasil belajar siswa kelas XI SMA/MA.

\section{METODE PENELITIAN}

Penelitian ini termasuk jenis penelitian dan pengembangan atau Research and Development (R\&D), yaitu penelitian yang digunakan untuk menghasilkan produk tertentu dan menguji keefektifan produk tersebut (Sugiyono, 2012). Produk dalam penelitian ini berupa modul kesetimbangan kimia berbasis pendekatan saintifik. Model pengembangan mengacu pada model pengembangan perangkat 4-D model, yaitu define, design, develop, dan disseminate (Thiagarajan, Sivasailam, et al. 1974), namun penelitian ini baru dilakukan sampai tahap develop.

Pada tahap define (pendefinisian) dilakukan lima analisis, yaitu: analisis ujung depan (awal-akhir), siswa, tugas, konsep dan tujuan pembelajaran. Analisis awal-akhir bertujuan untuk mengidentifikasi masalah yang dihadapi guru dan siswa dalam pembelajaran kimia khususnya pada materi kesetimbangan kimia. Analisis siswa bertujuan untuk mengidentifikasi target pembelajaran yaitu peserta didik. Analisis tugas berupa analisis Kompetensi Inti (KI), Kompetensi Dasar (KD) dari materi kesetimbangan kimia sesuai silabus Kurikulum 2013. Analisis konsep dilakukan untuk mengidentifikasi, merinci dan menyusun secara sistematis konsep-konsep materi kesetimbangan kimia. Pada analisis tujuan pembelajaran dilakukan perumusan tujuan pembelajaran kesetimbangan kimia dari indikator yang telah dirumuskan.

Pada tahap design (perancangan), dirancang modul kesetimbangan kimia berbasis pendekatan saintifik untuk pembelajaran kimia di SMA/MA sesuai dengan komponenkomponen modul, yaitu judul, kompetensi yang akan dicapai, petunjuk penggunaan, peta konsep, lembar kegiatan, lembar kerja, lembar evaluasi, kunci jawaban lembar kerja dan kunci lembar evaluasi (Prastowo, Andi. 2011). Tahapan pendekatan saintifik dengan kegiatan $5 \mathrm{M}$ terintegrasi pada modul, yaitu pada lembaran kegiatan. Kegiatan 5M tersebut, yaitu mengamati (observing), menanya (questioning), mencoba (experimenting), mengasosiasikan dan mengkomunikasikan

(Kemendikbud. 2013).

(networking)

Pada tahap develop (pengembangan) dilakukan uji validitas, praktikalitas dan efektifitas modul terhadap hasil belajar siswa SMA. Uji validitas ini bertujuan untuk melihat kelayakan isi, kebahasaan dan penyajian materi kesetimbangan kimia dalam modul berbasis 
pendekatan saintifik yang disusun. Instrumen yang digunakan berupa angket yang terdiri dari lembar validitas untuk dosen dan guru kimia serta lembar praktikalitas untuk guru kimia dan siswa. Untuk uji efektifitas digunakan intrumen berupa tes hasil belajar kognitif.

Validitas produk dilakukan oleh delapan pakar, yaitu lima dosen kimia FMIPA Universitas Negeri Padang dan tiga guru kimia SMA Negeri 2 Batusangkar. Pemilihan pakar didasarkan pada pendapat Sugiyono yang menyatakan bahwa untuk menguji validitas, dapat digunakan pendapat ahli (judgment experts) yang jumlahnya minimal tiga orang (Sugiyono. 2012).

Uji praktikalitas bertujuan untuk mengetahui praktikalitas modul yang dikembangkan, yaitu mengetahui sejauh mana manfaat, kemudahan penggunaan, dan efisien dari segi waktu pembelajaran dengan menggunakan modul kesetimbangan kimia berbasis pendekatan saintifik. Penilaian ini dilakukan oleh 4 guru kimia dan 25 siswa kelas XI MIA SMAN 2 Batusangkar.

Data hasil uji validitas dan praktikalitas yang diperoleh dianalisis menggunakan momen kappa seperti persamaan 1 dan kategori keputusan pada Tabel 1 (Boslaugh. 2008)

$$
\text { Moment kappa }(\mathrm{k})=\frac{\mathrm{P}-\mathrm{Pe}}{1-\mathrm{Pe}}
$$

Keterangan: $k=$ Moment kappa yang menunjukkan validitas produk; $\mathrm{P}=$ Proporsi yang terealisasi, dihitung dengan cara jumlah nilai yang diberi oleh validator dibagi jumlah nilai maksimal; Pe = Proporsi yang tidak terealisasi, dihitung dengan cara jumlah nilai maksimal dikurangi dengan jumlah nilai total yang diberi validator dibagi jumlah nilai maksimal.

Tabel 1. Kategori Keputusan berdasarkan Moment Kappa (k) (Boslaugh. 2008).

\begin{tabular}{cc}
\hline Interval & Kategori \\
\hline $0,81-1,00$ & Sangat tinggi \\
$0,61-0,80$ & Tinggi \\
$0,41-0,60$ & Sedang \\
$0,21-0,40$ & Rendah \\
$0,01-0,20$ & Sangat rendah \\
$\leq 0,00$ & Tidak valid \\
\hline
\end{tabular}

Efektifitas modul terhadap hasil belajar, diketahui melalui penelitian eksperimen semu Group Posttest Only Design (Tabel 2).

Tabel 2. Desain Penelitian (Sugiyono. 2012)

\begin{tabular}{ccc}
\hline Sampel & Perlakuan & Tes Akhir \\
\hline Kelas Eksperimen (R) & $\mathrm{X}_{1}$ & $\mathrm{O}_{1}$ \\
Kelas Kontrol (R) & $\mathrm{Y}_{1}$ & $\mathrm{O}_{2}$ \\
\hline
\end{tabular}

Populasi penelitian seluruh siswa kelas XI MIA SMAN 4 Padang tahun pelajaran 2015/2016 yang terdiri dari 6 kelas. Sampel diambil dengan menggunakan teknik cluster sampling. Kelas yang terpilih sebagai kelompok sampel adalah kelas XI MIA 1 sebagai kelas 
eksperimen dan kelas XI MIA 2 sebagai kelas kontrol. Kelas eksperimen belajar menggunakan modul kesetimbangan kimia berbasis pendekatan saintifik dan kelas kontrol belajar seperti yang biasa dilakukan oleh guru sebelumnya (tanpa modul).

Instrumen penelitian yang digunakan adalah tes hasil belajar kognitif berupa soal pilihan ganda dengan lima pilihan jawaban. Tes yang digunakan sesuai dengan materi yang diberikan selama perlakuan berlangsung. Untuk mendapatkan tes yang baik, terlebih dahulu dilakukan uji validalitas tes, reliabilitas tes, tingkat kesukaran dan daya beda soal. Setelah melakukan berbagai uji pada 40 soal uji coba, maka diperoleh 20 soal yang dapat digunakan untuk tes akhir.

Untuk menguji kebenaran hipotesis, yaitu "Hasil belajar siswa yang menggunakan modul berbasis pendekatan saintifik lebih tinggi secara signifikan dari pada hasil belajar siswa yang tidak menggunakan modul berbasis pendekatan saintifik pada materi kesetimbangan kimia kelas XI di SMA Negeri 4 Padang", maka dilakukan uji hipotesis. Uji hipotesis dilakukan dengan menguji kesamaan rata-rata (uji satu pihak), yaitu pihak kanan. Sebelum uji hipotesis terlebih dahulu dilakukan uji normalitas dan uji homogenitas.

Dari hasil uji normalitas dan homogenitas dari hasil tes akhir diperoleh bahwa kedua kelas sampel terdistribusi normal dan memiliki varians yang homogen. Oleh karena itu analisis data dilakukan dengan uji-t menggunakan persamaan (2) (Sudjana, 2005).

$$
\mathrm{t}=\frac{\overline{\mathrm{x}}_{1}-\overline{\mathrm{x}}_{2}}{\mathrm{~s} \sqrt{\frac{1}{\mathrm{n}_{1}}+\frac{1}{\mathrm{n}_{2}}}}
$$

Simpangan

menggunakaan persamaan (3) (Sudjana, 2010).

$$
\mathrm{S}=\sqrt{\frac{\left(\mathrm{n}_{1}-1\right) \mathrm{S}_{1}{ }^{2}+\left(\mathrm{n}_{2}-1\right) \mathrm{S}_{2}{ }^{2}}{\mathrm{n}_{1}+\mathrm{n}_{2}-2}}
$$

keterangan: $\mathrm{x}_{1}=$ nilai rata-rata siswa kelas eksperimen; $\mathrm{x}_{2}=$ nilai rata-rata siswa kelas kontrol; $\mathrm{s}=$ simpangan baku; $\mathrm{n}_{1}=$ jumlah siswa kelas eksperimen; $\mathrm{n}_{2}=$ jumlah siswa kelas kontrol; Kriteria pengujian adalah terima Ho jika $\mathrm{t}<\mathrm{t}_{1-\alpha}$ dan tolak Ho jika $\mathrm{t}$ mempunyai harga-harga yang lain (Sudjana, 2010).

\section{HASIL DAN PEMBAHASAN}

\section{Tahap Pendefenisian (define)}

Pada tahap ini diperoleh lima data yaitu data analisis ujung depan, analisis siswa, analisis tugas, analisis konsep, dan analisis tujuan pembelajaran. Kelima data tersebut diuraikan seperti berikut ini.

Analisis ujung depan

Kurikulum 2013 menuntut pelaksanaan pembelajaran yang berorientasi kepada siswa aktif. Siswa dituntut aktif dan mandiri dalam pembelajaran dan guru berperan sebagai fasilitator dan motivator. Karaketristik pembelajaran kimia yang abstrak, membuat siswa lebih cenderung mengandalkan kemampuan menghafal untuk menguasai materi kesetimbangan kimia. Hal ini membuat siswa kurang memahami materi ini. Kegiatan pembelajaran dengan pendekatan saintifik diasumsikan membuat siswa mampu mencapai pembelajaran yang dituntut kurikulum 2013. Hal ini sesuai dengan hasil penelitian yang melaporkan bahwa pembelajaran menggunakan pendekatan scientific efektif dalam meningkatkan keterampilan elaborasi siswa pada materi kesetimbangan kimia kelas XI IPA SMA Negeri 1 Purbolinggo semester ganjil Tahun Pelajaran 2013-2014. Tahapan-tahapan dalam pendekatan saintifik cenderung mengekplorasi keterampilan elaborasi siswa pada tahap mengamati, mencoba, dan menalar. Pembelajaran menggunakan pendekatan saintifik dapat mempermudah siswa untuk memahami materi yang disampaikan dan lebih membuat siswa untuk bertindak aktif pada proses pembelajaran (Purwaningsih, dkk. 2014).

Perangkat pembelajaran berbasis pendekatan saintifik juga berpengaruh terhadap hasil belajar siswa, baik dalam bentuk RPP maupun bahan ajar. Fauziah, dkk. (2013) melaporkan bahwa RPP berbasis pendekatan saintifik melalui model pembelajaran PBL berhasil memotivasi dan menanamkan sikap internal pada peserta didik. Yeni, dkk.(2015) juga melaporkan bahwa handout berorientasi pendekatan saintifik berpengaruh secara signifikant terhadap peningkatan hasil belajar IPA-fisika siswa kelas XI SMP Pertiwi Padang. 
Siswa yang menggunakan handout berorientasi pendekatan saintifik lebih mudah memahami langkah saintifik yang diterapkan dalam pembelajaran dan lebih aktif memahami materi secara berkelompok sesuai langkah yang tertera pada handout. Selanjutnya Bohori, dkk. (2015), melaporkan lembar kegiatan siswa berorientasi pendekatan saintifik dalam pembelajaran fisika berpengaruh terhadap pencapaian kompetensi kognitif siswa, nilai rata-rata kelas eksperimen lebih tinggi dari kelas kontrol.

Hasil penelitian juga menunjukkan bahwa penggunaan modul dapat merangsang motivasi intrinsik siswa untuk belajar kimia, motivasi intrinsik siswa yang belajar kimia menggunakan modul lebih tinggi secara signifikan dibandingkan dengan pembelajaran konvensional (tanpa modul) (Vaino, Katrin. et al. 2012).

Berdasarkan latarbelakang di atas maka pada penelitian ini dikembangkan modul kesetimbangan kimia berbasis pendekatan saintifik untuk pembelajaran kimia kelas XI SMA/MA.

Analisis Siswa

Dalam penelitian ini siswa yang dijadikan sebagai subjek penelitian adalah siswa SMA kelas XI yang berusia antara 15-17 tahun. Menurut Piaget usia 12 tahun ke atas disebut periode operasional formal, tahap ini merupakan tahap akhir dari perkembangan kognitif secara kualitas. Anak pada tahap ini sudah mampu mengadakan penalaran dengan menggunakan hal-hal abstrak. Penalaran yang terjadi dalam struktur kognitifnya telah mampu menggunakan simbol-simbol, ide-ide, abstraksi dan generalisasi. Ia telah memiliki kemampuankemampuan untuk melakukan operasi-operasi yang menyatakan hubungan di antara hubungan-hubungan, memahami konsep promosi (Santrock. 2008). Berdasarkan teori Piaget tersebut, maka menyediakan bahan ajar seperti modul sangat sesuai dengan karakteristik siswa SMA/MA.

Pada modul materi pelajaran disajikan secara lengkap, siswa dituntun untuk mempelajari, memahami, mengerjakan lembar kegiatan dan lembaran kerja serta lembaran evaluasi secara mandiri atau dengan bimbingan guru seminimal mungkin. Kegiatan ini akan membuat siswa aktif, kreatif dan berfikir kritis, sehingga tujuan pembelajaran dapat tercapai. Analisis Tugas

Berdasarkan hasil analisis KI dan KD yang terdapat dalam silabus kimia-minat SMA kurikulum 2013, dijabarkan beberapa indikator pembelajaran. Materi pokok kesetimbangan kimia terintegrasi pada KD 3.8, 3.9, 4.8, dan 4.9. Selanjutnya dilakukan perumusan indikator pembelajaran dan diperoleh enam indikator sebagai berikut (1) menjelaskan pengertian kesetimbangan kimia; (2) menjelaskan pengertian tetapan kesetimbangan; (3) meramalkan arah pergeseran kesetimbangan dengan menggunakan azas Le Chatelier; (4) menjelaskan pengaruh perubahan konsentrasi, suhu, tekanan dan volume terhadap pergeseran kesetimbangan; (5) melakukan percobaan salah satu faktor-faktor yang mempengaruhi pergeseran arah kesetimbangan, dan (6) menjelaskan penerapan konsep kesetimbangan dalam industri.

\section{Analisis Konsep}

Sesuai indikator pembelajaran, maka diperoleh beberapa konsep utama dan konsep yang relevan pada materi kesetimbangan kimia. Konsep utama yaitu (1) reaksi reversibel; (2) kesetimbangan dinamis; (3) kesetimbangan homogen; (4) kesetimbangan heterogen; (5) konstanta kesetimbangan (Kc dan $\mathrm{Kp}$ ); (6) pergeseran kesetimbangan; (7) azas Le Chatelier; dan (8) penerapan kesetimbangan dalam industri. Konsep-konsep relevan atau prasyarat diantaranya laju reaksi, molaritas, reaksi endoterm dan reaksi eksoterm.

Konsep-konsep utama dan prasyarat ini dianalisis dari beberapa buku kimia perguruan tinggi dan buku kimia SMA yang relevan, seperti buku karangan Brady (2010), Tro Nivaldo J (2011), Hiskia Ahmad (2001), Syukri. S (1999), Raimon Chang (2005), Fajar Partana (2009), Michael Purba (2004), dan Irvan Permana (2009) serta beberapa sumber yang relevan dari internet. Konsep-konsep yang diperoleh dibuatkan dalam suatu tabel analisis konsep yang terdiri dari label konsep, definisi konsep, jenis konsep, atribut konsep, posisi konsep, contoh dan non contoh. Tabel analisis konsep ini berguna untuk membuat peta konsep 
dan pedoman dalam menyusun isi materi pada modul.

\section{Analisis tujuan pembelajaran}

Berdasarkan indikator pembelajaran, maka dirumuskan tujuan pembelajaran. Tujuan pembelajaran kesetimbangan kimia untuk kelas XI SMA/MA adalah (1) menjelaskan pengertian kesetimbangan kimia dengan tepat; (2) menentukan tetapan kesetimbangan dengan benar; (3) menjelaskan arah pergeseran kesetimbangan berdasarkan azas Le Chatelier dengan benar; (4) menjelaskan pengaruh perubahan konsentrasi, suhu, tekanan dan volume terhadap pergeseran kesetimbangan dengan benar; (5) menyimpulkan pengaruh perubahan konsentrasi pada pergeseran kesetimbangan berdasarkan percobaan yang dilakukan dengan benar dan (6) menjelaskan kondisi optimum untuk memproduksi bahanbahan kimia di industri dengan tepat.

\section{Tahap Perancangan (design)}

Pada tahap ini dihasilkan rancangan awal modul kesetimbangan kimia berbasis pendekatan saintifik untuk pembelajaran kimia kelas XI SMA/MA. Bagian-bagian dari modul yang dirancang sesuai dengan komponen modul yang dikemukakan Prastowo, Andi. (2011), yaitu: (a) halaman depan (cover), (b) kompetensi inti, kompetensi dasar, indikator pembelajaran dan tujuan pembelajaran, (c) peta konsep (d) petunjuk belajar atau petunjuk penggunaan modul, (e) isi materi (f) lembar kerja (LK), (g) evaluasi, (h) kunci evaluasi dan (i) daftar pustaka.

Materi pada modul disusun berdasarkan tujuan pembelajaran dengan mengunakan beberapa buku kimia perguruan tinggi dan buku kimia SMA/MA yang relevan seperti yang dijelaskan pada analisis konsep sebelumnya. Tahapan pendekatan saintifik (5M) diintegrasikan pada modul, yaitu pada bagian lembar kegiatan.

\section{Tahap Pengembangan (develop)}

Pada tahap ini diperoleh tiga data, yaitu data hasil uji validitas, praktikalitas dan efektifitas modul, seperti uraian berikut ini.

\section{Hasil uji validitas modul}

Tabel 3 menunjukkan hasil uji validitas modul oleh validator. Dari Tabel 3 , terlihat bahwa modul kesetimbangan kimia yang dikembangkan sudah valid dari semua aspek penilaian yaitu, kelayakan isi, komponen kebahasaan, penyajian, dan kegrafikan.

Dari komponen kelayakan isi, modul memiliki kategori kevalidan sangat tinggi, artinya modul sudah sesuai dengan tuntutan KI dan KD pada silabus kimia kurikulum 2013 yang dituangkan pada Permendikbud Nomor 59 Tahun 2014.

Dari komponen kebahasaan, diperoleh nilai k 0.81 dengan kategori kevalidan tinggi, artinya modul lugas, komunikatif, dialogis dan interaktif, dan sesuaian dengan perkembangan siswa. Penggunaan kalimat pada modul jelas, mudah dipahami dan tidak menimbulkan kerancuan, sehingga mudah dimengerti oleh siswa. Sesuai dengan hal-hal yang harus diperhatikan dalam menyusun bahan ajar menurut Steffen Peter dalam Depdiknas (2008:18) yaitu bahasa yang mudah menyangkut jelasnya kalimat dan kemudahan dibaca.

Tabel 3. Hasil uji validitas modul oleh 8 orang validator

\begin{tabular}{clcc}
\hline No & Komponen yang dinilai & Nilai k & Kategori \\
\hline 1 & Kelayakan isi & 0.87 & Sangat Tinggi \\
2 & Kebahasaan & 0.81 & Tinggi \\
3 & Penyajian & 0.83 & Sangat Tinggi \\
4 & Kegrafikan & 0.84 & Sangat Tinggi \\
\hline & k-validitas & 0.84 & Sangat Tinggi \\
\hline
\end{tabular}


Dari komponen penyajian, diperoleh nilai k 0.83 dengan kategori kevalidan sangat tinggi, artinya modul telah disusun secara sistematis, mengacu pada tujuan pembelajaran yang jelas. Materi pada modul juga sudah disajikan secara lengkap sesuai dengan urutan pada indikator (Amri, Sofian. 2013). Modul telah sesuai dengan pendekatan saintifik yaitu berisi kegiatan mengamati, menanya, mengumpulkan data, mengasosiasikan, dan mengkomunikasikan hasil (Permendikbud, 2013).

Dari komponen kegrafikan, diperoleh nilai k 0.84 dengan kategori kevalidan sangat tinggi, artinya modul sudah lengkap, karena sudah meliputi uraian modul, desain kulit modul, dan desain isi modul sudah sesuai dengan standar penilaian bahan ajar oleh BNSP (2016). Modul juga sudah menggunakan jenis dan ukuran huruf yang sesuai dan jelas, layout atau tampilan cover dalam modul menarik perhatian siswa, sehingga siswa termotivasi untuk belajar. Begitu juga gambar dan ilustrasi yang digunakan dapat diamati dengan jelas dan dapat menyampaikan pesan secara efektif kepada siswa (BNSP, 2016).

Secara keseluruhan modul kesetimbangan kimia berbasis pendekatan saintifik yang dikembangkan telah valid dengan nilai k 0.8 dengan kategori sangat tinggi. Untuk kesempurnaan modul ini, maka masih perlu revisi secara terus-menerus sehingga dapat digunakan dalam pembelajaran kimia di SMA/MA.

\section{Hasil uji praktikalitas modul}

Tabel 4 menunjukkan hasil uji praktikalitas modul oleh guru dan siswa, terlihat bahwa modul yang dikembangkan memiliki kategori kepraktisan sangat tinggi. Modul yang dikembangkan sudah praktis, baik dari segi kemudahan penggunaan, efisiensi waktu pembelajaran dan manfaatnya.

Tabel 4. Hasil Uji Praktikalitas Modul oleh guru dan siswa

\begin{tabular}{clcc}
\hline \multirow{2}{*}{ No } & \multirow{2}{*}{ Aspek yang Dinilai } & \multicolumn{2}{c}{ Nilai k } \\
\cline { 3 - 4 } & Guru & Siswa \\
\hline 1 & Kemudahan Penggunaan & 0.89 & 0.91 \\
2 & Efisiensi Waktu & & \\
3 & Pembelajaran & 0.77 & 0.84 \\
3 & Manfaat & 0.85 & 0.86 \\
\hline \multicolumn{2}{c}{ k-praktikalitas } & 0.84 & 0.87 \\
\hline Kategori & \multicolumn{2}{c}{ Sangat tinggi } \\
\hline
\end{tabular}

Dari aspek kemudahan penggunaan, menunjukkan bahwa di dalam modul terdapat materi yang jelas, bahasa yang digunakan mudah dipahami, huruf yang digunakan mudah dibaca, ukuran modul praktis dan mudah dibawa (Depdiknas, 2008). Modul yang dikembangkan memudahkan guru dalam meningkatkan aktivitas siswa dalam pembelajaran. Seperti yang dikatakan Sukardi (2011) pertimbangan praktikalitas dapat dilihat dari aspek-aspek kemudahan penggunaan.

Dari aspek efisiensi waktu pembelajaran, menunjukkan bahwa dengan menggunakan modul waktu pembelajaran menjadi lebih efisien dan siswa dapat belajar sesuai dengan kecepatan belajarnya masisng-masing. Dilihat dari aspek manfaat, modul dikategorikan sangat praktis. Hal ini menunjukkan bahwa modul yang dikembangkan sudah sesuai dengan fungsi modul sebagai bahan ajar mandiri, sehingga siswa dapat memanfaatkan modul untuk belajar sendiri tanpa tergantung kepada kehadiran guru (Prastowo, Andi. 2011). Pembelajaran dengan modul juga bermanfaat bagi guru, modul mendukung peran guru sebagai fasilitator, pembelajaran dengan modul mengurangi beban 
kerja guru untuk menjelaskan materi berulangulang, dan guru mudah memantau aktifitas belajar siswa. Kesimpulan yang diperoleh dari
Tabel 2, didukung oleh data analisis jawaban siswa dalam menjawab pertanyaan-pertanyaan yang ada pada lembaran kegiatan (Tabel 5).

Tabel 5. Persentase siswa yang menjawab lembaran kerja siswa pada modul dengan benar.

\begin{tabular}{cc}
\hline Pertanyaan pada Lembar Kerja (LK) & Persentase jawaban benar \\
\hline LK 1.a & $85 \%$ \\
LK 1.b & $74 \%$ \\
LK 1.b & $93 \%$ \\
\hline Rata-rata keseluruhan & $84 \%$ \\
\hline
\end{tabular}

Tabel 6. Deskripsi Data Hasil Tes Akhir Kelas Sampel.

\begin{tabular}{cccc}
\hline \multirow{2}{*}{ Skor } & \multirow{2}{*}{ Nilai } & \multicolumn{2}{c}{ Frekuensi Kelas } \\
\cline { 3 - 4 } & & Eksperimen & Kontrol \\
\hline 12 & 60 & 1 & - \\
13 & 65 & 1 & 5 \\
14 & 70 & - & 7 \\
15 & 75 & 3 & 9 \\
16 & 80 & 9 & 6 \\
17 & 85 & 12 & 5 \\
18 & 90 & 6 & - \\
\hline & $\Sigma \mathrm{N}$ & 32 & 32 \\
\hline
\end{tabular}

Dari Tabel 5, terlihat bahwa $84 \%$ siswa sudah bisa menjawab pertanyaan yang ada pada lembar kegiatan dengan benar. Berdasarkan data pada Tabel 3, 4 dan 5, maka dapat disimpulkan bahwa modul kesetimbangan kimia berbasis pendekatan saintifik yang dikembangkan sudah valid dan praktis, sehingga dapat digunakan dalam pembelajaran kimia kelas XI SMA/MA. Oleh karena itu selanjutnya dilakukan uji efektifitas modul terhadap hasil belajar siswa.

Dari Tabel 6 terlihat hasil belajar siswa kelas eksperimen lebih tinggi dari pada kelas kontrol. Dari Tabel 6, dapat ditentukan

\section{Hasil uji efektifitas modul}

Efektifitas modul dapat dilihat dari pengaruhnya terhadap hasil belajar siswa. Penilaian hasil belajar dilakukan dengan memberikan tes akhir berupa tes objektif dengan 5 pilihan jawaban sebanyak 20 butir soal. Siswa yang menjawab benar diberi skor 1 (satu) dengan nilai 5 (lima) dan siswa yang menjawab salah diberi skor 0 (nol) dengan nilai 0 (nol). Deskripsi data hasil tes akhir kelas sampel dapat dilihat pada Tabel 6 . persentase ketuntasan siswa (nilainya di atas KKM, yaitu 79), seperti pada Gambar 1. 


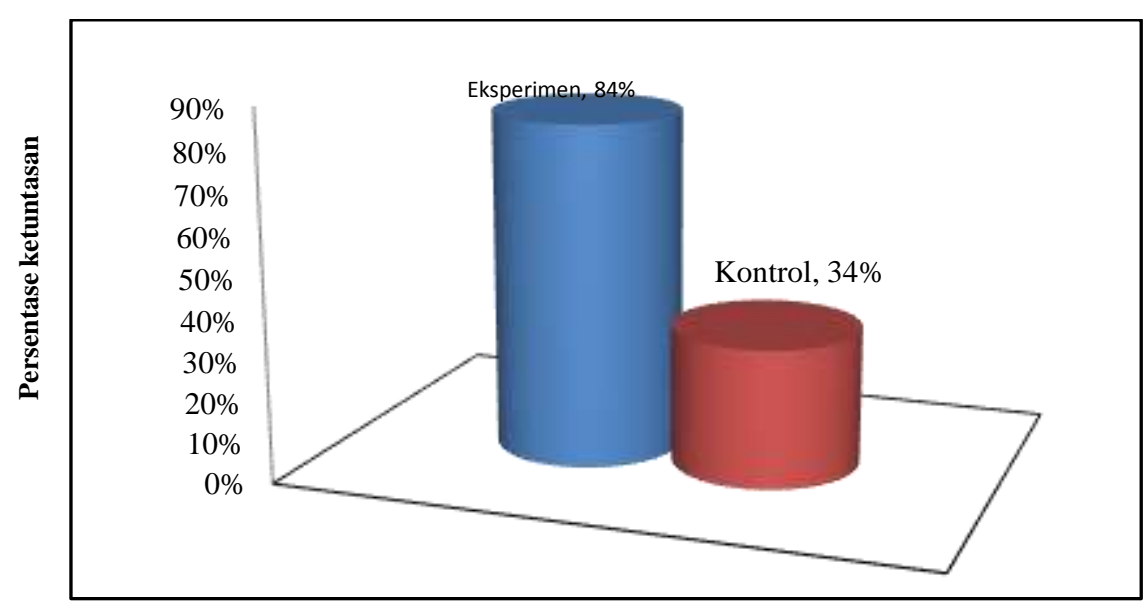

Gambar 1. Persentase ketuntasan siswa kelas sampel.

Gambar 1 menunjukkan bahwa peresentase ketuntasan siswa kelas eksperimen (84\%) lebih tinggi dari kelas kontrol (34\%), artinya penggunaan modul efektif terhadap hasil belajar siswa, karena secara klasikal sudah hampir $85 \%$ siswa yang tuntas (nilainya di atas KKM). Untuk menganalisis kebenaran data hasil penelitian yang sudah diperoleh pada Tabel 4 dan Gambar 1, maka dilakukan analisis data.

Analisis data dilakukan dengan cara berurutan, mulai dari melihat perbedaaan nilai kelas eksperimen dan kelas kontrol, uji normalitas, uji homogenitas dan uji hipotesis. Nilai hasil belajar siswa pada kelas sampel diolah secara statistik sehingga diperoleh nilai rata-rata $(\overline{\mathrm{x}})$ seperti pada Gambar 2.

Dari Gambar 2, terlihat nilai rata-rata kompetensi kognitif kelas eksperimen lebih tinggi dari kelas kontrol. Untuk menguji apakah terdapat pengaruh penggunaan modul terhadap hasil belajar secara signifikan atau tidak, maka dilakukan uji hipotesis. Sebelum uji hipotesis, terlebih dahulu dilakukan uji normalitas dan uji homogenitas terhadap hasil tes akhir masingmasing kelas sampel.

Uji normalitas bertujuan untuk melihat apakah kelas sampel berasal dari populasi yang terdistribusi normal. Untuk uji normalitas digunakan uji Liliefors. Hasil perhitungan dari uji normalitas kedua kelas sampel diperoleh $\mathrm{L}_{0}$ dan $\mathrm{L}_{\mathrm{t}}$ dengan taraf nyata $\alpha=0,05$ seperti yang terangkum pada Tabel 7 .

Dari Tabel 7, terlihat kedua kelas sampel memperoleh nilai $\mathrm{L}_{0}<\mathrm{L}_{\mathrm{t}}$. Data ini menunjukkan bahwa kedua kelas sampel terdistribusi normal. Untuk menentukan kedua kelas sampel memiliki varians yang homogen atau tidak, dilakukan uji homogenitas dengan menggunakan uji F. Dari hasil analisis uji homogenitas kedua kelas sampel diperoleh $F_{\text {hitung }}$ dan $F_{\text {tabel }}$ pada taraf nyata $\alpha=0.05$ (Gambar 3), terlihat bahwa $F_{\text {hitung }}>F_{\text {tabel}}$, sehingga dapat disimpulkan bahwa kelompok kelas sampel memiliki varians yang homogen. 


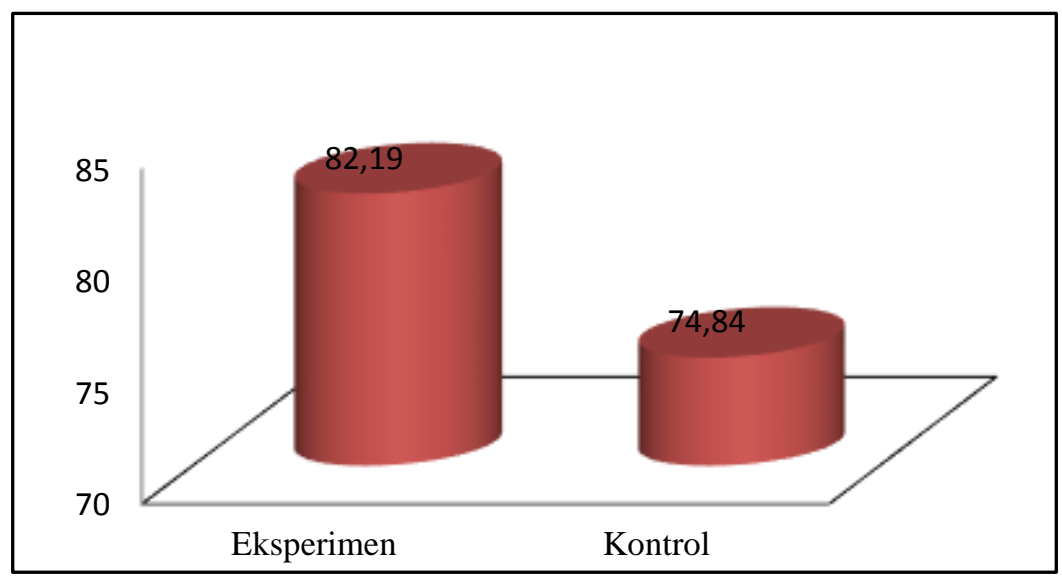

Gambar 2. Nilai rata-rata kompetensi kognitif kelas sampel

Tabel 7. Hasil Uji Normalitas terhadap Tes Akhir Kelas Sampel

\begin{tabular}{ccccc}
\hline Kelas & $\mathrm{L}_{0}$ & $\mathrm{~L}_{\mathrm{t}}$ & Analisis & Distribusi \\
\hline Eksperimen & 0.153 & 0.157 & $\mathrm{~L}_{0}<\mathrm{L}_{\mathrm{t}}$ & Normal \\
Kontrol & 0.148 & 0.157 & $\mathrm{~L}_{0}<\mathrm{L}_{\mathrm{t}}$ & Normal \\
\hline
\end{tabular}

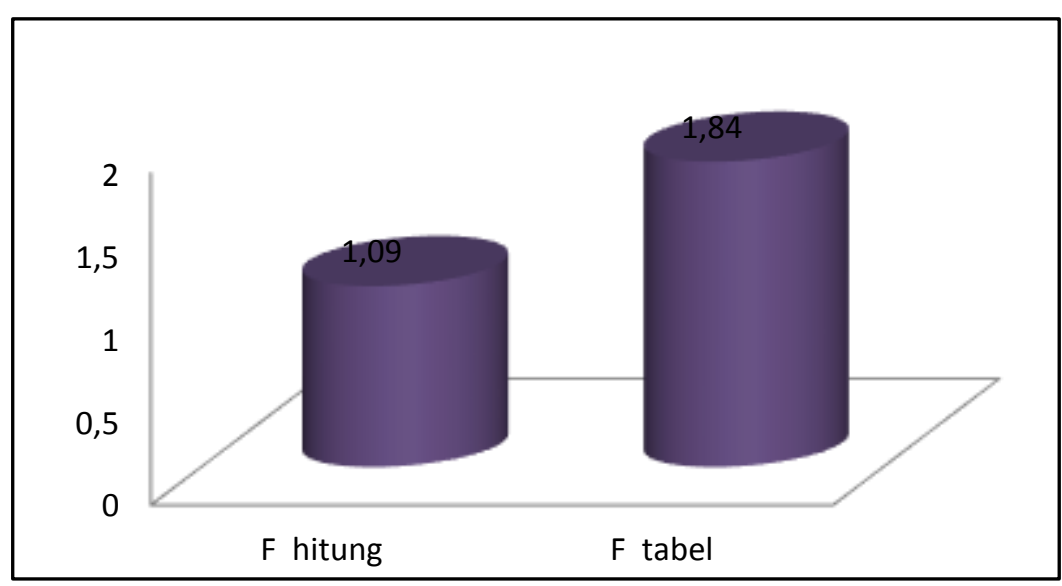

Gambar 3. Hasil Uji Homogenitas terhadap Hasil Tes Akhir Kelas Sampel

Hasil uji normalitas dan homogenitas kelas eksperimen dan kelas kontrol menunjukkan bahwa kedua kelas sampel terdistribusi normal dan memiliki varians yang homogen. Oleh karena itu untuk menguji hipotesis digunakan uji-t. Hasil uji hipotesis dapat dilihat pada Gambar 4.

Gambar 4 menunjukkan bahwa pada taraf nyata $\alpha=0,05$ harga $t_{\text {hitung }}>t_{\text {tabel }}$, sehingga dapat dinyatakan bahwa modul kesetimbangan kimia berbasis pendekatan saintifik berpengaruh secara signifikan terhadap hasil belajar siswa pada kompetensi kognitif di kelas XI MIA SMAN 4 Padang dan hipotesis penelitian 
diterima. Hasil ini menunjukkan bahwa modul kesetimbangan kimia berbasis pendekatan saintifik efektif digunakan untuk pembelajaran kimia kelas XI SMA/MA.

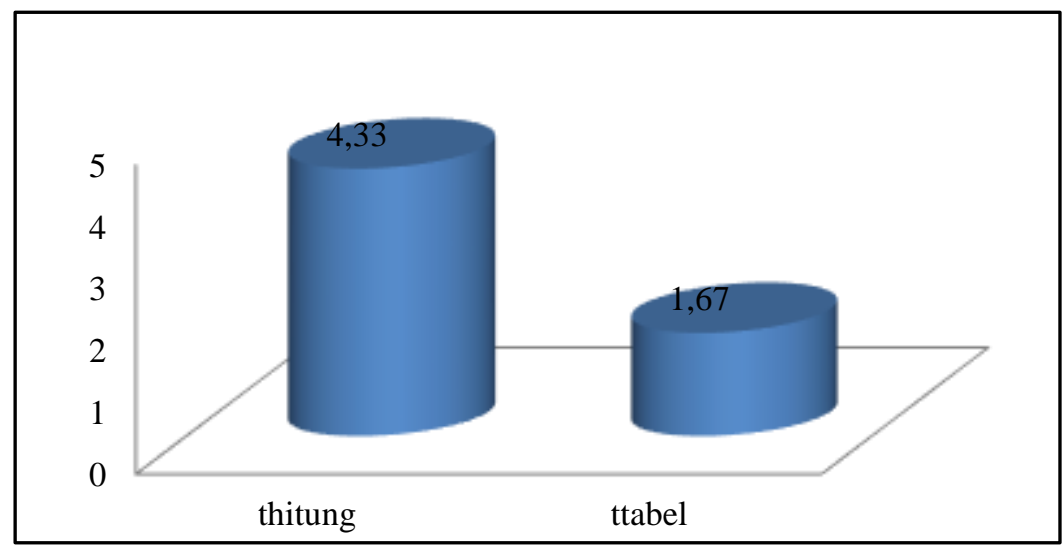

Gambar 4. Hasil Uji Hipotesis terhadap Hasil Tes Akhir Kelas Sampel

Pembelajaran dengan modul membuat siswa aktif, berfikir kreatif dan membantu siswa menemukan konsep. Hal ini sesuai dengan teori belajar Bruner yang menyatakan bahwa proses belajar akan berjalan dengan baik jika guru memberikan kesempatan kepada siswa untuk menemukan konsep, teori, aturan, atau pemahaman melalui contoh-contoh yang dijumpainya dalam kehidupan sehari-hari (Budiningsih, Asri. 2012). Hasil yang diperoleh sejalan dengan hasil penelitian Novianty Iqma, dkk, yaitu modul efektif meningkatkan hasil belajar siswa dan persepsi siswa terhadap isi modul serta pembelajaran dengan bantuan modul sangat positif. Selain itu keefektifan modul kesetimbangan kimia disebabkan karena, modul disusun berdasarkan pendekatan saintifik yang yang dikenal dengan 5M.

Pada tahap mengamati, siswa difasilitasi untuk melakukan pengamatan dengan kegiatan membaca, menyimak, melihat (tanpa atau dengan alat) yang disajikan pada modul. Pada tahap ini siswa menghubungkan pengetahuan awal yang dimiliki dengan fenomena yang sekarang dihadapi. Kegiatan mengamati sangat bermanfaat bagi penumbuhan rasa ingin tahu peserta didik, sehingga proses pembelajaran memiliki kebermaknaan yang tinggi (Majid, Abdul dan Rochman, Chaerul. 2014). Kegiatan mengamati juga dapat melatih kesungguhan dan ketelitian peserta didik (Hosnan. 2014). Hal ini sesuai dengan pernyataan Piaget yang menyatakan bahwa ilmu pengetahuan dibangun dalam pikiran seorang anak dengan kegiatan asimilasi, akomodasi dan ekuilibrasi. Asimilasi ialah pemaduan data baru dengan stuktur kognitif yang ada. Akomodasi ialah penyesuaian struktur kognitif terhadap situasi baru, dan equilibrasi ialah penyesuaian kembali yang terus dilakukan antara asimilasi dan akomodasi (Budiningsih, Asri. 2012).

Pada tahap menanya yaitu "tanya kenapa", siswa difasilitasi untuk mengidentifikasi dan menuliskan hal-hal yang tidak dipahami pada kegiatan mengamati dalam bentuk pertanyaan-pertanyaan sederhana pada modul. Hal ini sesuai dengan pandangan dasar dalam kurikulum 2013 bahwa pembelajaran harus berkenaan dengan kesempatan yang diberikan kepada peserta didik untuk mengkonstruksi pengetahuan dalam proses kognitifnya (Hosnan. 2014). Kegiatan menanya 
dapat menumbuhkan rasa ingin tahu siswa serta kemampuan merumuskan pertanyaan untuk melatih berpikir kritis.

Pada tahap mencoba/mengumpulkan informasi, pada modul ini disediakan lembar kegiatan yang berisi petunjuk praktikum dan pertanyaan-pertanyaan yang menuntun siswa untuk dapat membangun konsep berdasarkan rumusan masalah yang diajukan. Pada tahap ini siswa akan terbiasa bekerjasama dalam kelompok sehingga akan menumbuhkan sikap disiplin, jujur, teliti, taat aturan dan kerja keras dalam melakukan kegiatan pembelajaran maupun diskusi dalam kelompok (Hosnan. 2014). Kegiatan ini membuat proses pembelajaran menjadi efektif, karena semua siswa di dalam kelompoknya melakukan praktikum, diskusi dan berintekrasi dengan guru dalam menyelesaikan lembar kegiatan tersebut. Menurut teori asosiasi, proses pembelajaran akan berhasil secara efektif jika terjadi interaksi langsung antara pendidik dengan peserta didik (Hosnan. 2014 dan Elizar. 2012). Jika siswa tidak mencapai KKM, siswa dapat mengulang kembali mengerjakan lembar kegiatan tersebut sampai siswa tersebut merasa puas dengan nilai yang diperolehnya.

Pada tahap mengkomunikasikan, siswa menyampaikan hasil pengamatan atau kesimpulan secara tulisan pada lembaran yang telah disediakan pada modul atau secara lisan melalui persentasi di kelas. Melalui kegiatan mengkomunikasikan siswa mengembangkan nilai-nilai karakter seperti: sikap jujur, teliti, toleransi, kemampuan berfikir sistematik, mengungkapkan pendapat dengan jelas dan mengembangkan kemampuan berbahasa yang baik dan benar (Hosnan. 2014). Pendekatan saintifik mempermudah siswa untuk memahami materi yang disampaikan dan lebih membuat siswa untuk bertindak aktif (Purwaningsih, dkk. 2014).

Lembaran evaluasi dan kunci jawaban yang ada pada modul membantu siswa untuk menguji kemampuannya sendiri terhadap materi yang telah dipelajarinya. Dengan demikian siswa dapat belajar sendiri atau dengan bimbingan guru seminimal mungkin yang akhirnya akan berpengaruh terhadap peningkatan hasil belajar siswa.

\section{KESIMPULAN}

Berdasarkan analisis hasil penelitian, maka disimpulkan bahwa modul kesetimbangan kimia berbasis pendekatan saintifik untuk pembelajaran kimia SMA/MA yang dikembangkan memiliki kriteria valid, praktis dan efektif. Oleh karena itu modul ini dapat digunakan untuk pembelajaran kimia sesungguhnya di SMA/MA kelas XI.

\section{DAFTAR KEPUSTAKAAN}

Amri S. 2013. Pengembangan dan Model Pembelajaran dalam Kurikulum 2013. Jakarta: PT Prestasi Pustakaraya.

Badan Standar Nasional Pendidikan (BNSP). 2006. Standar Penilaian Bahan Ajar.

Bohori, Muhammad, Putra, Amali dan Razi, Pakhrur. 2015. Pengaruh Lembar Kegiatan Siswa Berorientasi Pendekatan Saintifik dalam Pembelajaran Fisik Terhadap Pencapaian Kompetensi Siswa. Pillar of Physisc Education. Vol. 5. April 2015 hal :161-168.

Brady JE. 2010. Chemistry The Moleculer Nature Of Matter $6^{\text {th }}$ Edition. John Wiley and Sons: New York.

Boslaugh S dan Paul AW. 2008. Statistics in a Nutshell, a desktop quick reference. Beijing, Cambridge, Famham, Köln, Sebastopol, Taipei, Tokyo: O'reilly.

Budiningsih A. 2012. Belajar dan Pembelajaran. Jakarta: PT Rineka Cipta.

Departemen Pendidikan Nasional. 2008. Pengembangan Bahan Ajar. Jakarta: Departemen Pendidikan Nasional, Direktorat Jenderal Manajemen Pendidikan Dasar dan Menengah, Direktorat Pembinaan Sekolah Menengah Atas.

Elizar. 2012. Pengembangan Program Pembelajaran. Padang: UNP Press.

Fauziah R. Abdullah AG, Hakim DL. 2013. Pembelajaran Saintifik Elektronika Dasar Berorientasi Pembelajaran Berbasis Masalah. Jurnal Invotec. Vol 9, No 2 hal : 165-178. 
Hosnan. 2014. Implementasi Saintifik dan Kontekstual dalam Pembelajaran Abad 21. Bogor: Ghalia Indonesia

Kemendikbud. 2013. Materi Pelatihan Guru: Implementasi Kurikulum 2013. Jakarta.

Lewis G. TT. The Nature of Science and the Scientific Method. America: Geology Society of America.

Majid A dan Rochman C. 2014. Pendekatan Ilmiah dalam Implementasi Kurikulum 2013. Bandung: PT Remaja Rosdakarya.

Novianty I, Oktavia S dan Neena Z. Efektivitas Penerapan Modul Materi Analisis Elektrokimia Berbasis Inkuiri Terbimbing Terhadap Hasil Belajar Dan Persepsi Siswa Kelas XI Semester 1 Kompetensi Keahlian Kimia Analisis SMKN 7 MALANG. Universitas Negeri Malang: jurnal-online.um.ac.id.

Permendikbud Nomor 59 Tahun 2014 tentang Kurikulum 2013 Sekolah Menengah Atas/Madrasah Aliyah.

Prastowo A. 2011. Panduan Kreatif Membuat Bahan Ajar Inovatif. Yogyakarta: Diva Press

Purwaningsih E, Fadiawati N dan Kadaritna N. 2014. Penggunaan Pendekatan Scientific pada Pembelajaran Kesetimbangan Kimia dalam Meningkatkan Keterampilan Elaborasi. Jurnal Pendidikan dan Pembelajaran Kimia. Vol. 3 No. 1 hal: 1-14.

Santrock JW. 2008. Psikologi Pendidikan (Educanitional psychology). Edisi 3 Buku 1. Penerjemah Diana Angelica. Jakarta: Salemba Humanika.

Sawitri DW. 2014. "Pengembangan Modul Keanekaragaman Hayati Berbasis Pendekatan Saintifik Untuk Kelas X SMA". Jurnal Penelitian. Vol 3 No.3 Agustus 2014. FMIPA: Universitas Negeri Surabaya.

Sudjana N. 2010. Penilaian Hasil Proses Belajar Mengajar. Bandung: PT Remaja Rosda Karya.

Sukardi. 2011. Evaluasi Pendidikan, Prinsip, Dan Operasionalnya. Yogyakarta: Bumi Aksara.
Sugiyono. 2012. Metode Penelitian Kuantitatif kualitatif dan $R \& D$. Bandung: Penerbit Alfabeta.

Vaino K, Jack H and Miia R. 2012. Stimulating students' intrinsic motivation for learning chemistry through the use of context-based learning modules. Chemistry Education Research and Practice. Vol. 13, 410-419.

Yeni, Giffi F, Putra, Amalia dan Hufri. 2015. Pengaruh Handout Berorientasi Pendekatan Saintifik Terhadap Hasil Belajar IPA-Fisika Siswa Kelas IX SMP Pertiwi 2 Padang. Pillar of Physisc Education. Vol. 5. hal: 97-104.

Yerimadesi, Budhi O, dan Wilda ZF. 2015. The Development of Discovery LearningBased Module in Buffer Solution Topic for Senior High School Instruction. Proceeding The International Conference on Mathematics, Science, Education and Technology (ICOMSET). Chemistry Education. Hal: 206-210.

Thiagarajan S, et al. 1974. Instructional Development for Training Teachers of Exceptional Children: A Sourcebook. Washington, D.C: Indiana University, Bloomington. 